\title{
Sex reversal, growth, and survival in the swordtail fish Xiphophorus helleri (Cyprinodontiformes: Poeciliidae) under laboratory conditions
}

\author{
A. A. Ortega-Salas, H. Reyes-Bustamante and H. Reyes B. \\ Instituto de Ciencias del Mar y Limnología, UNAM. Calz. Joel M. Camarena s/n Apdo. Post. 811, Mazatlán 82040, México; \\ ortsal@ola.icmyl.unam.mx
}

Received 9-X-2012 Corrected 30-I-2013 Accepted 11-VI-2013

\begin{abstract}
The fish Xiphophorus helleri is a commercially important species. Here we analyze several cultivation variables. We studied them for 120 days in 10-gallon aquaria without aeration; 1 fry per liter, the temperature varied between 26,3 and $26,9^{\circ} \mathrm{C}$. The $\mathrm{pH}$ ranged from 8,1 to 8,8 and the oxygen concentration from 6,2 to $6,6 \mathrm{mg} / \mathrm{L}$. Api-aba balanced fodd with $25 \%$ protein was used, three hormones were added: 1) Sten 2) Primoteston and 3) Sostenon 250. Sex reversal was $84,3 \%, 91,4 \%$ and $93,3 \%$ correspondingly. A fish with treatment 1 gained an average of $0,55 \mathrm{~g}$ and total length of $5,4 \mathrm{~cm}$, with treatment $2: 0,59 \mathrm{~g}$ and $5 \mathrm{~cm}$; and with treatment 3: $0,55 \mathrm{~g}$ and $4,1 \mathrm{~cm}$. The $8^{\text {th }}$ fortnight survival was $80 \%, 90 \%$ and $75 \%$ correspondingly; these differences are not statistically significant. The three treatments gave the expected results of sex reversal, growth and survival.
\end{abstract}

\section{KEY WORDS}

Sexual revertion, animal feed, population density, hormone supply, aquaria without aeration

\section{RESUMEN}

El pez Xiphophorus helleri es una especie comercial muy importante. Aquí analizamos distintas variables de cultivo. Las estudiamos durante 120 días en acuarios de 10 galones, sin aireación; se utilizaron densidades de 1 alevín por litro, la temperatura varió entre 26,3 y $26,9^{\circ} \mathrm{C}$. El valor del pH de 8,1 a 8,8 y la concentración de oxígeno de 6,2 a 6,6mg/L. Se utilizó alimento balanceado Api-aba con $25 \%$ de proteína, se les adicionó tres hormonas: 1) Sten, 2) Primoteston y 3) Sostenon 250. La reversión sexual correspondiente fue de $84,3 \%, 91,4 \%$ y $93,3 \%$. Los peces con el tratamiento 1 ganaron un promedio de $0,55 \mathrm{~g}$ de peso y longitud total de $5,4 \mathrm{~cm}$, con el tratamiento $2: 0,59 \mathrm{~g}$ y $5 \mathrm{~cm}$ y con el $3: 0,55 \mathrm{~g}$ y $4,1 \mathrm{~cm}$. La sobrevivencia en 8 quincenas fue de $80 \%, 90 \%$ y $75 \%$ correspondientemente. Los resultados de las pruebas estadísticas indican que las diferencias no son siginificativas. Los tres tratamientos ofrecieron los resultados esperados de reversión sexual, crecimiento y supervivencia.

\section{PALABRAS CLAVE}

Reversión sexual, alimento balanceado, densidad poblacional, suministro hormonal, acuarios sin aireación
The first living specimens of Xiphophorus helleri (Heckel, 1848) were exported from Mexico in 1909, but the species was known since the description by James Heckel based on material collected by Cart Heller near Veracruz in 1845. Heckel did not name Xiphophorus (etymologically, back sword carrier), by the extension in the lower rays of the caudal fin in males, but most breeders associate the "sword" to the caudal extension (Aries, 1977). This fish dwells in the shores of Southern Mexico and Guatemala. The length of the body (without the sword) is $8 \mathrm{~cm}$, and the female can reach $12 \mathrm{~cm}$.
Sex reversal involves the production of organisms of the same sex through the application of steroids to fry, which have not yet defined the gonads (Hernández, 1989). Manipulation with steroid and growth hormones has been applied to salmonids, cyprinids and cichlids used for human consumption and on a larger scale in cyprinids, cichlids, and poeciliids used as ornament species, which are currently the primary base of production in ornamental fish industry (Dawes, 1991).

The process of sexual differentiation in the teleost fishes is diverse and labile, it is possible to obtain sexual 
reversion with the application of steroids in several gonocoristics and some hermaphrodite species (Francis, 1992). This method aims to produce populations of a single sex. However, it is important to identify the labile period in which the gonad can be influenced by hormones to successfully achieve the sexual reversal (Cabeza, 1995; Hunter \& Donaldson, 1983). There are two characteristics related with the determination of the sex of ornamental fish, which allows the successful implementation of the technique of sex reversal: (1) sex in fish is determined in a relatively final state in the development of juveniles ( 3 to 4 weeks after hatching) when juveniles measure less than $20 \mathrm{~mm}$ in length, $y$ (2) sex is unstable soon after hatching and can be affected by internal and external factors. The administration of androgens during this critical period can reverse completely the fry population or at least most males. The most convenient and effective method is oral administration of hormones incorporated into feed fry (Hepher \& Pruginin, 1985).

Shelton, Hopkins and Jensen (1978) mentioned that each hormone produces different results, and in addition they should make large numbers of recently born more or less uniform. Growth of fry in tanks and the hormone treatment period depends on density and temperature, and there are many types of androgens, which can be used but, when provided orally, the most active are: ethyl (et) and methyl testosterone testosterone (mt).

In the present investigation hormones were directly applied to the offspring through food in three different treatments to analyze sexual reversion, growth and survival.

\section{MATERIALS AND METHODS}

The study was conducted in the Culture Laboratory, Faculty of Sciences of the Sea, Universidad Autónoma de Sinaloa and at the fish hatchery of Hacienda Xochimancas, Morelos, Mexico; under controlled water, air, and temperature.

\section{Determination of physicochemical factors}

Physico-chemical samples (temperature, $\mathrm{pH}$ and oxygen) were taken, since the beginning of the introduction of the organisms, every 15 days. Temperature was recorded with a thermometer (Broken) scale - 20 to $110^{\circ} \mathrm{C}$ with an accuracy of \pm 1 digit. $\mathrm{pH}$ was determined with a potentiometer (Corning brand) with accuracy of \pm 1 digit. Oxygen was determined with an Oximeter model 57, YSI brand.

\section{Determination of biological factors}

Fifty female fish from the Fish Farming Centre of Xochimancas in the State of Morelos. Transportation was in plastic bags $25 \times 40 \mathrm{~cm}, 30 \%$ of water. They were placed separately in 10-gallon tanks at a rate of 10 organisms per aquarium. They were subsequently treated with a prophylactic bath salt from 3 to 15 minutes. They were fed live food (Daphnia magna).

Organisms were placed separately in a 10 gallon aquaria for reproduction, 5 ovigerous females (6-7 months old). The eggs are not fertilized over 48 hours. Sexual maturity occurs between 6 and 10 months, although some subspecies take from 2 to 5 months.

\section{Growth and sexual reversal tests}

Growth tests were made for 120 days in aquaria without aeration. The specimens were deposited in Petri dishes during the early larval stage and measured with the help of the traced area with a hematocytometer (which has divisions of 50, 200, and $1000 \mu \mathrm{m}$ ) and a stereoscopic microscope. When the larvae measured more than $5 \mathrm{~mm}$ we used a Petri and millimetric paper for the same measurement. The weight was recorded with a balance (Granataria GT 480 Ohaus, 0,000g); 1 per litre breeding densities were used, temperature was controlled from 26 to $28^{\circ} \mathrm{C}$ by means of a Sunny $\mathrm{G} 50 \mathrm{w}$ thermostat. We fed them pet food (Api-aba with $25 \%$ protein). Three different hormones were added to three treatments: (1) Sten, (2) Primoteston and (3) Sostenon 250. Primostenon contains testosterone enanthate; $250 \mathrm{mg}$, Sten Propranato testosterone; $20 \mathrm{mg}$, ciclopentil Propianato of testosterone; $75 \mathrm{mg}$ and Dehydroisoandrosterone; $20 \mathrm{mg}$ and Sostenon, testosterone Propianato; $30 \mathrm{mg}$, testosterone Fenilpropianato; $60 \mathrm{mg}$, testosterone Isocaproato: $60 \mathrm{mg}$ and testosterone decanoate. We recorded the total length $(\mathrm{L})$ and weight $(\mathrm{W})$ for 120 days. The rate of growth in length $(L)$ was obtained by performing linear regression and the weight (W) with Bertalanffy method (1935).

Growth hormone food: (1) $500 \mathrm{~g}$ of food Api-Aba with $25 \%$ protein, finely ground, (2) $4 \mathrm{ml}$ of hormone diluted in $300 \mathrm{ml}$ of ethyl alcohol, (3) uniformly mixing the alcohol, hormone and food, (4) are dried in the shade, and (5) is stored in an airtight container to prevent moisture.

\section{Survival}

Survival test was performed for 120 days from newborn fish, counted daily. All tests were initiated with 40 fry at a density of 1 org/L (Fig. 4). 
The Kruskal-Wallis analysis was used to see if there were significant differences among results.

\section{RESULTS}

Temperature varied between 26,3 and $26,9^{\circ} \mathrm{C}$. The $\mathrm{pH}$ varied from 8,1 to 8,8 and the concentration of oxygen varied 6,2 to $6,8 \mathrm{mg} / \mathrm{L}$.

Sexual reversion (gonopodium formation) was with treatment 1 between 35 and 45 days, with treatment 2 between 32 and 42 days, and with treatment 3 between 36 and 45 days. They fish reached $84,3 \%$ sex reversal with treatment 1,91,4\% treatment 2, and 93,3\% treatment 3.

Figure 1 shows the maximum value of growth in length with $5,4 \mathrm{~cm}$ using treatment 1 and the minimum was $4,8 \mathrm{~cm}$

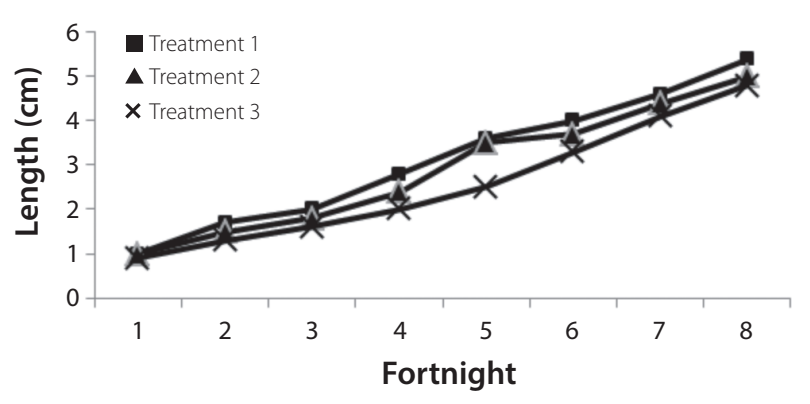

FIG. 1. Growth in length for 8 fortnight's periods.

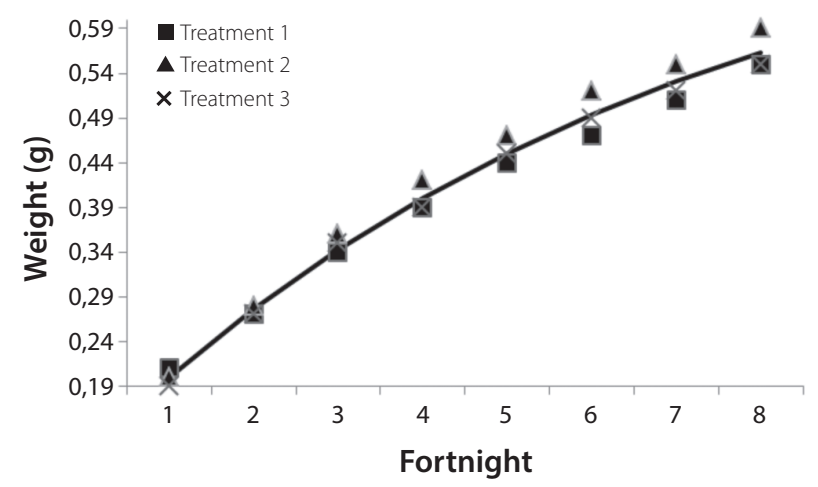

FIG. 2. Growth in weight (g) for 8 fortnight's periods. with treatment 3 during 120 days. They grew around $0,58 \mathrm{~cm}$ each fortnight. Figure 2 shows the maximum values of growth in weight of this fish, with $0,59 \mathrm{~g}$ using treatment 2 and the minimum was $0,55 \mathrm{~g}$ with treatments 1 and 3 . The von Bertalanffy parameters were as following: $K=0,146, L \infty=0,7666$, and $t_{0}=-1,0673$. The three treatments gave the following potential regression: Weight (g) $=0,2131 \ln \left(\right.$ Lengthcm) $+0,2116 R^{2}=0,94$ (Fig. 3).

Survival is represented by Figure 4 where treatment 2 has a high survival rate in the fifth fortnight with $90 \%$ (treatment 1 at sixth fortnight with 80\%), and treatment 3 (at seven fortnight with 75\%). After those fortnight survival values becamewas steady with treatment 2 (35 fish), treatment 1 (32 fish) and treatment 3 (30 fish). These values were not statistically different.

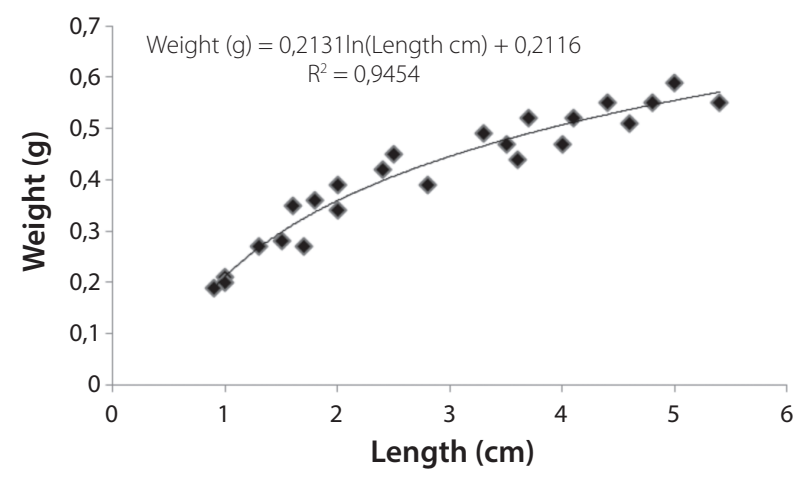

FIG. 3. Weight-length relationship in swordtail fish.

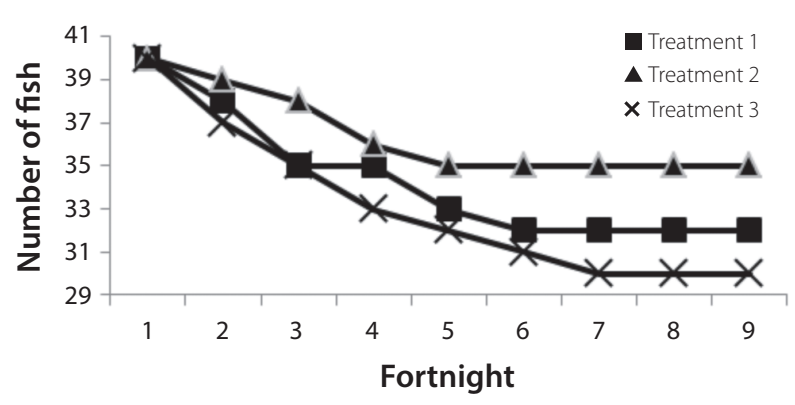

FIG. 4. Survival for 8 fortnight's periods. 


\section{DISCUSSION}

The optimum temperature to keep these fish is $20-30^{\circ} \mathrm{C}$, with a minimum of $18^{\circ} \mathrm{C}$. Axelrod (1993) mentions that the best temperature is about $25,5^{\circ} \mathrm{C}$. Temperature influences growth and gonadal maturation (Rodríguez, 1992).

In natural populations inhabiting ecologically impacted places, the decrease in $\mathrm{pH}$ values has caused massive fish kills in addition to a reduction in individual growth rates, population and reproductive disorders, and strains in the skeleton (Haines, 1981).

Hernández and Espinosa (1997), used steroids (19-nortriendiona and 17-a metiltestosterona) in the swordtail fish $X$. helleri. According to their results they obtained an efficiency of $92,3 \%$ with a concentration of $50 \mathrm{mg}$, $44,4 \%$ presented gonopodium and $55,6 \%$ gonopodium and sword. With 17 - metiltestosterona they obtained a $88,6 \%$ with concentration of $50 \mathrm{mg}(42,4 \%$ presented gonopodium and sword and 4,6\% were females). Peña \& Márquez (1997) administered the hormone diethyetilbestrol in food with a dose of $12,5 \mathrm{mg} / \mathrm{kg}$ and $10,0 \mathrm{mg} /$ $\mathrm{kg}$, this delayed the oogenesis (in contrast with $7,5 \mathrm{mg} /$ $\mathrm{kg}$ gonads, many oocytes full of vitellin and $5,0 \mathrm{mg} / \mathrm{kg}$ in embryos and control group). Rodríguez, Nava and De la Cruz. (1997) applied the hormone metiltestosterone to African fish (Oreochromis sp.), with $50 \mathrm{mg} / \mathrm{kg} 4$ times per day for 40 days and their fish grew slightly more than non-treated controls, but the survival was higher with the hormone treatment.

Kavumpurath \& Pandian (1993) used 9 (11)-androstenedione and dimetiltestosterone. They found that androstenedine androgen was naturally the most efficient in sexual reversion. With treatment 3 ) $X$. helleri produced very similar results, even if the methods of application of hormones were different. The above-mentioned authors applied the hormones to gravid females and in the present investigation they were applied directly to the young through the food.

Olivier \& Kaiser (1997) mentioned that in 14 weeks increasing stocking rates (6 per $\mathrm{L}$ ) resulted in a significant reduction of growth rates (final $0,48 \mathrm{~g} /$ fish); fish at the highest stocking density ( 6 per L) had a lower survival rate $(44,9 \%)$ than those kept at lower stocking densities (1 and 3 per $\mathrm{L}$ ).

The success of the masculinization may be explained by the fact that fry were treated on the first day of age, when the gonads are is a receptive stage, according to Goodrich, Dee, Flynn and Mercer (1934).

\section{ACKNOWLEDGEMENTS}

We thank A. Nuñez P.and S. Rendón R. for technical support.

\section{REFERENCES}

Aries S. S. (1977). Peces tropicales platyes y espadas. Argentina: Littec.

Axelrod, H. R. (1993). Crianza de los peces de ornato. España: Hispano Europea.

Bertalanffy, L. von. (1951). Theoretische Biologie. Stoowechsel, Wachustum: Zweiter Band.

Cabeza, M. (1995). Hormonas y reproducción. México: Universidad Autónoma Metropolitana.

Dawes, J. (1991). Live bearing fishes. England: Blanford.

Francis, C. (1992). Sexual lability in teleost: developmental factors. Quarterly Review of Biology, 67, 1-17.

Goodrich, H., Dee, I, Flynn, C., \& Mercer, N. (1934). Germ cells and sex diferentiation in Lebistes retícula/a. Bioliology Bulletin, $67,83-96$

Haines, T. (1981). Acid precipitation and its consequences for aquatic ecosysterns: a review. Transactions of the American Fisheries Society, 110(6), 669-707.

Hepher, B., \& Pruginin, Y. (1985). Cultivo de peces comerciales. México: Editorial Limusa.

Hernández, B.S. (1989). Uso de hormonas en la reproducción de peces. México: Ed. Fondepesca, Sepesca.

Hernández, O., \& Espinosa, D. E. (1997). Efectos de los csteroides 17 a metiltestosterona y 19 nortriendiona en la reversión sexual y crecimiento del pez cola de espada Xiphophorus helleri en condiciones de laboratorio. Res. V. Congreso Nacional de Ictiología. Mazatlán, Sinaloa, Mexico.

Hunter, G., \& Donaldson, E. (1983). Hormonal sex control and it's aplication to fish culture. In Hoar, W S. \& Donaldson, E. M. (eds) Fish Physiology, Reproduction. New York, USA.: Academic Press.

Kavumpurath, S., \& Padian, T. (1993). Masculinization of Poecilia reliculta by dietary administration of synthetic or natural androgen to gravid females. Aquaculture, 116, 83-89.

Olivier, A., \& Kaiser, H. (1997). A comparison of growth, survival rate, and number of marketable fish produced of swordtails, Xiphophorus helleri Heckel (Family Poeciliidae), between two types of culture systems. Aquaculture Research, 28(3), 215-221.

Peña, A. F. \& Márquez, E. A. (1997). Efecto de la hormona Diethyletilbestrol en hembras gravidas de X. helleri. V Congreso Nacional de Ictiología. Mazatlán, Sinaloa, México.

Rodríguez, G. M. (1992). Técnicas de evaluación cuantitativa de la madurez gonádica en peces. Chapingo. Serie Ciencias Forestales y del Ambiente, 3(1), 15-21. 
Rodríguez. G. M., Nava, B. J., \& De la Cruz, C. G. (1997). Efecto de la administración de la hormona Metiltestosterona sobre las proporciones sexuales en Oreochromis sp en acuanos. V Congreso Nacional de Ictiología. Mazatlán, Sinaloa, México.
Shelton, W. L., Hopkins, K. D., \& Jensen, G. L. (1978). Use of hormones to produce monosex Tilapia for aquaculture In Smitherman, R.D., Shelton, W.L. \& Grover, J.H. (Eds) Culture of Exotic Fishes. Syimposium Proceedings Fih Culture Section, American Fisheries Society Auburn, Alabama, USA. 
